\title{
Nutrition and Covid-19 epidemic
}

\author{
Tanja PAJK ŽONTAR ${ }^{1}$, Rajko VIDRIH ${ }^{1, *}$
}

Received November 30, 2020; accepted March 19, 2021.

Delo je prispelo 30. novembra 2020, sprejeto 19. marca 2021.

\section{Nutrition and Covid-19 epidemic}

Abstract: Proper nutrition is an essential part of an individual's defence against numerous diseases including coronavirus disease SARS-CoV-2 (Covid-19). Nutritional status of individual is affected by several factors such as age, sex, health status, physical activity, life style and medications. Optimal nutrition and dietary nutrient intake impact the immune system, therefore the sustainable way to survive in current context is to strengthen the immune system. Inadequate intake of energy, protein, and specific micronutrients are associated with depressed immune function and increased susceptibility to infection. Predominantly vital for the encouraging of immune function are elements selenium, iron and zinc and vitamins $A, D$, $\mathrm{C}, \mathrm{E}, \mathrm{B}_{6}, \mathrm{~B}_{9}$ (folate) and $\mathrm{B}_{12}$ as well as omega- 3 polyunsaturated fatty acids. Thus, during this time it is important to take care of nutritional habits, following a healthy and balanced nutritional pattern containing a high amount of elements, antioxidants and vitamins. It is also recommended, that individuals should be mindful of physical activity, known to be associated with allcause mortality. Regular physical activity also improves mental health and overall feelings of wellbeing. Thus, now in the time of epidemic, more than ever, wider access to healthy foods should be a top priority for governments around the world

Key words: nutrition; Covid-19; immune system; nutrients; vitamins; elements; antioxidants; omega-3 polyunsaturated fatty acids

\section{Prehrana in epidemija Covid-19}

Izvleček: Pravilna prehrana je pomemben del posameznikove obrambe pred številnimi boleznimi, vključno pred koronavirusno boleznijo SARS-CoV-2 (Covid-19). Na prehranski status posameznika vpliva več dejavnikov, kot so starost, spol, zdravstveno stanje, telesna dejavnosti, življenjski slog in uživanje zdravil. Optimalna prehrana in $\mathrm{z}$ njo vnos hranil vplivata na imunski sistem, zato je trajnostni način preživetja $\mathrm{v}$ sedanjih okoliščinah krepitev imunskega sistema. Neustrezen vnos energije, beljakovin in določenih mikrohranil je povezan z oslabljenim delovanjem imunskega sistema in povečano dovzetnostjo za okužbe. Za spodbujanje imunske funkcije so pomembni predvem elementi selen, železo in cink ter vitamini $\mathrm{A}, \mathrm{D}, \mathrm{C}$, $\mathrm{E}, \mathrm{B}_{6}, \mathrm{~B}_{9}$ (folati) in $\mathrm{B}_{12}$ ter večkrat nenasičene maščobne kisline omega-3. V obdobju epidemije je zato še toliko bolj pomembno skrbeti za zdravo in uravnoteženo prehrano, ki vsebuje dovolj elementov, antioksidantov in vitaminov.Priporočljivo je tudi, da se posamezniki zavedajo pomena redne telesne dejavnosti, za katero je znano, da zmanjšuje tveganje za smrtnost zaradi različnih vzrokov. Redna telesna dejavnost ima tudi ugoden vpliv na duševno zdravje in splošno počutje. Širši dostop do zdrave hrane bi v danih okoliščinah morala biti ena izmed prednostnih nalog vlad po vsem svetu.

Ključne besede: prehrana; Covid-19; imunski sistem; hranila; vitamin; elementi; antioksidanti; večkrat nenasičene maščobne kisline omega-3

1 University of Ljubljana, Biotechnical Faculty, Department of Food Science and Technology, Ljubljana, Slovenia

* rajko.vidrih@bf.uni-lj.si 


\section{INTRODUCTION}

At the time of this writing, the Covid-19 pandemic will have infected more than 125 million people and taken the lives of nearly 2,800,000 individuals world-wide. Data for Slovenia (2 million inhabitant) in the moment are not encouraging, nearly 210,000 infected since the beginning and 4,280 lives taken till $25^{\text {th }}$ of March, 2021.

Proper nutrition, with the aim to maintain immune function is an essential part of an individual's defence against Covid-19. Optimal nutrition and dietary nutrient intake impact the immune system through gene expression, cell activation, and signalling molecules modification. In addition, various dietary ingredients are determinants of gut microbial composition and subsequently shape the immune responses in the body (Aman \& Masood, 2020). Adequate intake of energy, protein, and specific micronutrients are associated with depressed immune function and increased susceptibility to infection. Predominantly vital for the strengthening of immune function are elements selenium, iron and zinc and vitamins $\mathrm{A}, \mathrm{D}, \mathrm{E}, \mathrm{C}, \mathrm{B}_{6}$ and $\mathrm{B}_{12}$ and omega- 3 polyunsaturated fatty acids (Naja \& Hamadeh, 2020)

Therefore, the key to maintaining an effective immune system is to avoid deficiencies of the energy and nutrients that play an essential role in immune cell triggering, interaction, differentiation, or functional expression (Barazzoni et al., 2020).

Covid-19 does not treat the whole population equally, differences are due to genetics and lifestyle. World Health Organization exposed, that people who eat a wellbalanced diet tend to be healthier with stronger immune system and lower risk of chronic noncommunicable diseases and infectious diseases (WHO, 2020a). Undernourished people have weaker immune system, and may be at greater risk of severe illness due to the virus. At the same time, poor metabolic health, including obesity and diabetes, is strongly linked to worse Covid-19 outcomes, including risk of hospitalisation and death (Global ..., 2020). The high consumption rate of diets high in saturated fats, sugars, and refined carbohydrates (collectively called Western diet), and low levels of dietary fibre, unsaturated fats and antioxidants worldwide, contribute to the prevalence of obesity and type 2 diabetes, and could place these populations at an increased risk for severe Covid-19 pathology and mortality. Typical western diet consumption activates the innate immune system and impairs adaptive immunity, leading to chronic inflammation and impaired host defence against viruses (Butler et al., 2020)

There is not enough scientific evidence whether people with diabetes are more likely to get Covid-19 than the general population. General opinion is that people with diabetes are more likely to have serious complications from Covid-19. As seen from observations from Italy $30 \%$ of deceased people due to Covid-19 had diabetes (Antonio et al., 2020). Reports from Lombardy also suggest that anti diabetes medicines worsen the course of Covid-19 disease (Antonio et al., 2020).

In a future virus pandemic, we might face a "double burden" of malnutrition, when both undernutrition and overnutrition will promote severity of disease (Barazzoni et al., 2020).

This article explores the importance of nutrition to boost immunity and gives some professional and authentic dietary guidelines about nutrition and food safety to better withstand Covid-19. The food safety, food management, access to food and many other important topics related to Covid-19 and nutrition are not the issue of this article.

\section{NUTRITION AND COVID-19}

Nutritional deficiencies of energy, protein, and specific micronutrients are associated with depressed immune function and increased susceptibility to infection. A proper planned diet, comprised of well-balanced nutrients is crucial to health, supports normal B and $\mathrm{T}$ immune cell functions for optimal disease-reducing immunity. In the case of Covid-19, the goal of nutrition is to reduce infection and disease progression while improving recovery during the course of the disease (Jaggers et al., 2020).

\subsection{FRUITS AND VEGETABLES}

Food and Agriculture Organization put down seven healthy eating tips to face the Covid-19 crisis, first of them is dedicated how to strengthen our immune system through a proper diet. Focus should be put in consumption of at least five servings a day of fruits and vegetables, because they contain a lot of micronutrients, which can boost immune function. Some of these micronutrients such as vitamin C, A, C, E and beta-carotene are antioxidants that increase the number of T-cell subsets, enhance lymphocyte response to mitogen, increase interleukin-2 production, potentiate natural killer cell activity, and increase response to influenza virus vaccine compared with placebo (FAO, 2020; Muscogiuri et al., 2020).

\subsection{FATS AND OILS}

World Health Organization recommended to consume unsaturated fats, which are found in oils (sunflow- 
er, olive, soy, canola and corn), fish, avocado and nuts, rather than saturated fats from fatty meat, butter, coconut oil, cream, cheese, ghee and lard (WHO, 2020a).

Excessive saturated fats consumption can induce a lipotoxic state and activate the innate immune system via activation of toll-like receptor 4 expressed on macrophages, dendritic cells, and neutrophils. This triggers activation of canonical inflammatory signalling pathways that produce proinflammatory mediators and other effectors of the innate immune system (Rogero et al., 2020). Furthermore, consumption of a high fat diet in mice increased macrophage infiltration to lung tissue, specifically in the alveoli, which is especially relevant to Covid-19 patients given the high rate of infection among lung alveolar epithelial cells and the involvement of lung tissue inflammation and alveolar damage in Covid-19 pathology (Butler \& Barrientos 2020).

\subsubsection{Role of omega-3 fatty acids in immune system}

Omega-3 fatty acids are unsaturated long chain fatty acids known to decrease inflammation, which seems to be critical also for Covid-19 patients. Among them, eicosapentaenoic (EPA) and docosahexaenoic (DHA) are considered the most potential in inhibiting inflammation, could ameliorate some patients need for intensive care unit admission and have stimulating effect on immune system (Shakoor et al., 2020). Omega-3 fatty acids might inhibit growth of influenza virus, they are suggested to increase the oxygenation in Covid-19 patients (Barazzoni et al., 2020). From that point of view, patient therapy must consider omega- 3 fatty acids as a co-therapy in Covid-19 (Rogero et al., 2020). Both, EPA and DHA are found in fish and fish oils. Cod liver oil is of special interest from nutritional point of view due to the high content of natural vitamin $\mathrm{D}_{3}$ and vitamin $\mathrm{A}$ (retinol).

\subsection{VITAMINS AND ELEMENTS}

There is currently no guidance on micronutrient supplementation for the prevention of Covid-19 in healthy individuals or for the treatment of Covid-19. Wherever possible, micronutrient intakes should come from a nutritionally balanced and diverse diet, including fruits, vegetables and animal source foods (WHO, 2020b).

\subsubsection{Vitamin A and carotene}

Vitamin A has been defined as "anti-infective" vitamin since many of the body's defences against infection depend on its adequate supply. Vitamin A deficiency is involved in measles and diarrhoea and measles can become severe in vitamin A-deficient children (Barazzoni et al., 2020; Solomons, 2012). In experimental models, the effect of infection with infectious bronchitis virus, a kind of coronaviruses, was more pronounced in chickens, fed with a diet marginally deficient in vitamin A than in those fed a diet adequate in vitamin $\mathrm{A}$. It has also been reported that vitamin A supplementation in humans reduced morbidity and mortality in different infectious diseases, such as measles, diarrheal disease, measles related pneumonia, malaria and HIV/AIDS infection (Barazzoni et al., 2020).

The richest animal sources of vitamin $\mathrm{A}$ in the human diet are fish liver oils, liver, other organ meats, cream, butter, and fortified milks. Certain tropical fatty fruits are the richest sources of provitamin A (Solomons, 2012). Beta carotene (provitamin A) is most abundant in sweet potatoes, carrots and green leafy vegetables (Muscogiuri et al., 2020).

\subsubsection{Role of vitamin C in immune system}

There is no evidence found that supplements can cure or »boost « the immune system except vitamin C, which is one of the best way to improve immune system. Vitamin C is one of the major constituents of water soluble vitamins which tends to contribute to a strong immune system (Aman et al., 2020). The daily recommended dietary allowance for vitamin C is $110 \mathrm{mg} /$ day for men and $95 \mathrm{mg} /$ day for women (NIJZ, 2020).

Vitamin C, water soluble antioxidant acts by scavenging damaging reactive oxygen species, thus protecting the tissues from oxidative damage and dysfunction. It is known for long as a protective factor for infectious diseases acting as an antioxidant through inactivation of free radicals and thus protecting proteins, lipids and nucleotides against oxidative damage (Shakoor et al., 2020). It accumulates in leucocytes reaching 50-100 fold higher concentration as compared to its plasma content, but it is depleted fast in case of infection (Shakoor et al., 2020).

Patients with asthma and pneumonia are known to have low vitamin C content in plasma (Hunt et al., 1994). Among others, vitamin $\mathrm{C}$ also reduces pro-inflammatory cytokines and increases anti-inflammatory cytokines; administration of $1 \mathrm{~g}$ of vitamin $\mathrm{C}$ per day increases the anti-inflammatory cytokines (Shakoor et al., 2020). Covid-19 patients are very susceptible to pneumonia, intravenous administration of high vitamin improved inflammatory respiration parameters (Hiedra et al., 2020).

Sources of vitamins $\mathrm{C}$ include red peppers, oranges, strawberries, broccoli, mangoes, lemons, and other fruits and vegetables (Muscogiuri et al., 2020).

\subsubsection{Role of vitamin D in immune system}

Vitamin D deficiency in winter has been reported to be associated to viral epidemics. Adequate vitamin 
D status reduces the risk of developing several chronic diseases such as cancers, cardiovascular disease, diabetes mellitus, and hypertension that significantly increase risk of death from respiratory tract infections than otherwise healthy individuals. Further, vitamin D protects respiratory tract preserving tight junctions, destroying enveloped viruses through induction of cathelicidin and defending, and decreasing production of proinflammatory cytokines by the innate immune system, therefore reducing the risk of a cytokine storm leading to pneumonia (Muscogiuri et al., 2020).

Vitamin D seems to be tightly connected to the outcome of Covid-19 disease (Shakoor et al., 2020). Shortage of vitamin $\mathrm{D}$ is more pronounced in older people, at increased body weight, at men, hypertension, in higher geographic latitude and under conditions of higher coagulation (Shakoor et al., 2020). Older population is known to have chronic increased pro-inflammatory condition which render older people more susceptible to chronic diseases (Ferrucci et al., 2018). Vitamin D shortage pose a higher risk of community acquired pneumonia as has been reported in 8 studies including a total of 20966 patients as cited by Zhou et al., (2019). Sufficient consumption of vitamin D inhibits the synthesis of pro-inflammatory cytokines and limit the respiration stress connected to fatal outcome due to Covid-19 (Shakoor et al., 2020).

In the future, investigations will confirm whether insufficient vitamin D status more specifically characterizes Covid-19 patients and is associated to their outcome. In support to this hypothesis, decreased vitamin D levels in calves have been reported to enhance risk for bovine coronavirus infection (Barazzoni et al., 2020).

Since the time spent outdoor and consequently to the sun exposure is limited, especially during winter, it is encouraged to get more vitamin $\mathrm{D}$ from diet. Foods containing vitamin D include fish, liver, egg yolk and foods with supplemented vitamin D and food supplements (Muscogiuri et al., 2020).

\subsubsection{Role of zinc in immune system}

Essential trace element that is crucial for the maintenance of immune function is zinc. It has been reported that zinc inhibited severe acute respiratory syndrome (SARS) coronavirus RNA-dependent RNA polymerase template binding and elongation in Vero-E6 cells. Although oysters contain the most zinc per serving, the most common food to get zinc include poultry, red meat, nuts, pumpkin seeds, sesame seeds, beans, and lentils (Muscogiuri et al., 2020). The primary, relatively rich, plant source of zinc are whole-grain cereals. Zinc is mostly contained in the bran and germ portions, thus, nearly $80 \%$ of the total zinc in these foodstuffs can be lost in the wheat milling process (Holt et al., 2012).
Zinc is a microelement involved in numerous biological processes including the immune response to virus infections (Shakoor et al., 2020). Shortage of zinc increases pro-inflammatory cytokines, permeability of epithelial cells in lungs (Shakoor et al., 2020). Increased intake of zinc results in higher number of $\mathrm{T}$ cells that inhibit synthesis, replication and transcription of coronavirus (Te Velthuis et al., 2010).

Due to the above mentioned facts, administration of zinc to Covid-19 patients resulted in an improved infection symptoms of lower respiration tract (Finzi 2020).

\subsubsection{Role of Vitamin $B_{12}$ in immune system}

Serum vitamin $B_{12}$ also called as cobalamin is a crucial micronutrient in many aspects of healthy metabolism. It plays an important role in maintaining nerve tissue health, brain function and red blood cell synthesis (Naik et al., 2020).

In Singapore cohort study, Tan et al. (2020) reported that a combination of vitamin $\mathrm{D}$, magnesium and vita$\min B_{12}$ lessen the need for oxygen therapy and/or intensive care support.

Humans obtain vitamin $B_{12}$ from products of animal origin including meat, fish, shellfish, dairy products and eggs (Naik et al., 2020).

\subsubsection{Role of vitamin $E$ and selenium in immune system}

Vitamin E and selenium play an important role in antioxidative system, shortage of any of them might change immune response against viruses (Shakoor et al., 2020). The content of selenium in the diet is influenced by geographical location of production (Terry \& Diamond, 2012). Chinese researchers have proved the correlation between the content of selenium in soil from Chinese provinces and the course of the Covid-19 disease (Zhang et al., 2020). From that point of view the cure rate of Covid-19 patients inside Hubei Province, known as province with low soil selenium content, was significantly lower as compared to other provinces (Zhang et al., 2020). Selenium intake in humans originates principally from the consumption of meat, eggs and fish, which contain high levels of selenium in relation to other foods, ranging from 180 to $800 \mathrm{ng} / \mathrm{g}$. Most plants do not accumulate high levels of selenium, with some exceptions like the crops from Brassica genus, which includes broccoli and kale, garlic, mushrooms and brazil nuts, which contain the highest levels of bioavailable selenium (Terry \& Diamond, 2012).

Beside selenium alone, administration of selenium combined with vitamin $\mathrm{E}$ improved the immune response against respiratory infections (Wu et al., 2019). Rather than any of vitamin $\mathrm{E}$ isomers alone, the mixture of all four isomers proved to be more efficient than 
a-tocopherol alone due to the availability of more receptors (Liu et al., 2002).

The major dietary sources of vitamin $\mathrm{E}$ are vegetable oils (soybean, sunflower, corn, wheat germ, and walnut), nuts, seeds, spinach, and broccoli (Muscogiuri et al., 2020).

\subsubsection{Role of folate in immune system}

Folate play an important role in the synthesis, repair and methylation of DNA, cellular division and in the maturation of red blood cells.

Inadequate supplementation of folic acid results in abnormally large red blood cells that do not work properly. This results in an increased red cell distribution width (RDW), a blood parameter associated with folate deficiency anaemia, which can cause tiredness and other symptoms (Batool et al., 2013; Im et al. 2020).

Studies investigating folate concentration in plasma are scares. A significantly lower serum folate has been reported in Israel for patients with severe Covid-19 infection (Itelman et al., 2020).

In their review authors Acosta-Elias et al., (2020) hypothesize that pregnant women are less likely to acquire Covid-19 infection while those infected have a higher chance of being asymptomatic (Acosta-Elias \& Espinosa-Tanguma 2020).

Wiltshire et al. (2020) recommend a supplementation of folic acid at $5 \mathrm{mg}$ as a therapeutic option for pulmonary hypertension and severe hypoxaemia as well as for patients affected by severe Covid-19 pneumonia.

A number of plant and animal foods are rich sources of folate, including spinach, kale, broccoli, avocado, citrus fruits, eggs, and beef liver.

\subsection{HYDRATION}

World Health Organization and Food and Agriculture Organization recommended to drink at least two litres of water a day, as the best choice, to stay hydrated and support our immune system. Water transports nutrients and compounds in blood, regulates our body temperature, gets rid of waste, and lubricates and cushions joints (WHO, 2020a; FAO, 2020).

\section{RECENT FINDINGS REGARDING THE MOST COMMON NUTRITIONAL DEFFICIENCIES OF COVID-19 PATIENTS}

Im et al. (2020) investigated the contents of vitamin $\mathrm{B}_{1}, \mathrm{~B}_{6}, \mathrm{~B}_{12}$, vitamin $\mathrm{D}$ (25-hydroxyvitamin D), folate, selenium and zinc levels in 50 hospitalized patients with
Covid-19. Covid-19 patients were deficient primarily in vitamin D (76.0 \%) and selenium (42.0\%), while $6.0 \%$ of patients showed deficiency in both vitamin $\mathrm{B}_{6}$ and folate. Mechanically ventilated patients showed even higher deficiency in vitamin $\mathrm{D}(80.0 \%)$ and $100 \%$ deficiency in selenium (Im et al., 2020). Haematological parameter RDW is an indicator of red blood cells size, normal reference range of RDW-CV (Red Cell Distribution Width) in human red blood cells is $11.6-14.8 \%$. RDW is considered as biomarker indicative of cardiovascular disease (Borné et al., 2011). Higher RDW values are indication for inflammation and oxidative stress (Emans et al., 2011). Authors Batool et al., (2013) investigated the relationship between RDW and anaemia. They found $88.0 \%$ of older people with iron deficiency to have RDW higher than $14.8 \%$. On the other hand $44.0 \%$ of patients with vitamin $\mathrm{B}_{12}$ deficiency and $57 \%$ with folate deficiency had RDW higher than $14.8 \%$. In their recent investigation authors Foy et al. (2020) found elevated RDW(>14.5 $\%)$ associated with an increased mortality risk in patients of all ages in 4 hospitals in Boston, USA. They found mortality rate of $11 \%$ for patients with normal RDW and $31 \%$ of patients with an elevated RDW. The literature data regarding the control of RDW by healthy lifestyle are scarce. In their attempt to clarify the impact of lifestyle on RDW, Loprinzi et al., (2015) studied dietary data collection and accelerometer-determined physical activity. They found physical activity inversely associated with RDW but not healthy eating. The limitation of this study is that nutritionally important components were not analysed precisely but it was estimated using 2 recall surveys. However, there are sufficient indications that food rich in iron, vitamin $B_{12}$ and folate and probably other nutrients lower the RDW. Regarding physical activity, endurance sport seems to be beneficial in lowering RDW (Alis et al., 2015). Like for overall mortality, RDW seems to be a valuable predictor of mortality also for Covid-19 patients.

\section{CONCLUSION}

Individuals should be aware of healthy eating habits to reduce susceptibility to and long-term complications from Covid-19. Thus, now more than ever, wider access to healthy foods should be a top priority since people nutritional status strongly impact the outcome of Covid-19 patients. Recent nutritional status of Covid-19 patients shows a substantial deficiency in some nutritionally important compounds.

Eating a variety of nutritionally dense food is the recommended way to get nutrients we need. In some circumstances adding dietary supplements are recommended for specific groups like babies, pregnant women, 
elderly and the people with weak immune system on one side as well as for people diagnosed with specific diseases. Dietary supplements are also recommended for people with inadequate nutrition or when nutrition is not the adequate source of specific nutrients. Before taking dietary supplements it is recommended to talk with the doctor or pharmacist.

It seems that Mediterranean diet pattern could represent a healthy nutritional pattern to be followed under Covid-19 circumstances. Key ingredients of Mediterranean cuisine include fresh fruits and vegetables, fish, protein-rich legumes, olive oil and whole grains with moderate amounts of wine and red meat.

\section{REFERENCES}

Acosta-Elias, J., \& Espinosa-Tanguma, R. (2020). The folate concentration and/or folic acid metabolites in plasma as factor for COVID-19 infection. Frontiers in pharmacology, 11, 1062. https://doi.org/10.3389/fphar.2020.01062

Alis, R., Romagnoli, M., Primo-Carrau, C., Pareja-Galeano, H., Blesa, J. R. \& Sanchis-Gomar, F. (2015). Effect of exhaustive running exercise on red blood cell distribution width. Clinical Chemistry and Laboratory Medicine (CCLM), 53(2), e29-e31. https://doi.org/10.1515/cclm-2014-0749

Aman, F., \& Masood, S. (2020). How Nutrition can help to fight against COVID-19 Pandemic. Pakistan Journal of Medical Sciences, 36(COVID19-S4), S121-S123. https://doi. org/10.12669/pjms.36.COVID19-S4.2776

Antonio, S. G., Matteo, M., Achille, C., Enrica, V., Valentina, G., Salvatore, S., ... Edoardo, M. (2020). Are diabetes and its medications risk factors for the development of COVID-19? Data from a population-based study in Sicily. Nutrition, Metabolism and Cardiovascular Diseases, 31(2), 396398. https://doi.org/10.1016/j.numecd.2020.09.028

Barazzoni, R., Bischoff, S. C., Breda, J., Wickramasinghe, K., Krznaric, Z., Nitzan, D., .. S Singer, P. (2020). ESPEN expert statements and practical guidance for nutritional management of individuals with SARS-CoV-2 infection, Clinical Nutrition, 39(6), 1631-1638. https://doi.org/10.1016/j. clnu.2020.03.022

Batool, S., Wang, Q., Qureshi, S. \& Chua, E. (2013). The red cell diameter width distribution, the forgotten haematological parameter for anaemia in the older person. European Geriatric Medicine, 4, 1-4. https://doi.org/10.1016/j. eurger.2012.02.001

Borné, Y., Smith, J. G., Melander, O., Hedblad, B. \& Engström, G. (2011). Red cell distribution width and risk for first hospitalization due to heart failure: a population-based cohort study. European Journal of Heart Failure, 13(12), 13551361. https://doi.org/10.1093/eurjhf/hfr127

Butler, M. J., \& Barrientos, R. M. (2020). The impact of nutrition on COVID-19 susceptibility and long-term consequences. Brain, Behavior, and Immunity, 87, 53-54. https:// doi.org/10.1016/j.bbi.2020.04.040

Emans, M. E., van der Putten, K., van Rooijen, K. L., Kraaijen- hagen, R. J., Swinkels, D., van Solinge, W. W., ... Gaillard, C. A. (2011). Determinants of red cell distribution width (RDW) in cardiorenal patients: RDW is not related to erythropoietin resistance. Journal of Cardiac Failure, 17(8), 626-633. https://doi.org/10.1016/j.cardfail.2011.04.009

FAO. (2020). 7 healthy eating tip to face the COVID 19 crisis. Retrived from http://www.fao.org/americas/noticias/ver/ en/c/1267852/

Ferrucci, L., \& Fabbri, E. (2018). Inflammageing: chronic inflammation in ageing, cardiovascular disease, and frailty. Nature reviews. Cardiology, 15(9), 505-522. https://doi. org/10.1038/s41569-018-0064-2

Finzi, E. (2020). Treatment of SARS-CoV-2 with high dose oral zinc salts: A report on four patients. International Journal of Infectious Diseases, 99, 307-309. https://doi.org/10.1016/j. ijid.2020.06.006

Foy, B. H., Carlson, J. C., Reinertsen, E., Valls, R. P. I., Lopez, R. P., Palanques-Tost, E., ... Higgins, J. M. (2020). Association of red blood cell distribution with mortality risk in hospitalized adults with SARS-CoV-2 infection. JAMA Network Open, 3(9), e2022058-e2022058. https://doi:10.1001/ jamanetworkopen.2020.22058

Global Nutrition Report. (2020). 2020 Global Nutrition Report. Retrived from https:/globalnutritionreport.org/ reports/2020-global-nutrition-report/

Hiedra, R., Lo, K. B., Elbashabsheh, M., Gul, F., Wright, R. M., Albano, J., ...Aponte, G. P. (2020). The use of IV vitamin C for patients with COVID-19: a single center observational study. Expert Review of Anti-Infective Therapy, 18(12), 1259-1261. https://doi.org/10.1080/14787210.2020.17948 19

Holt, R. R., \& Uriu-Adams J. Y., \& Keen C. L. (2012). Zinc. In J. W. Erdman \& I. A. Macdonald \& S. H. Zeisel (Eds.), Present knowledge in Nutrition (pp. 521 - 539). Hong Kong, A John Wiley \& Sons, Ltd., Publication.

Hunt, C., Chakravorty, N., Annan, G., Habibzadeh, N. \& Schorah, C. (1994). The clinical effects of vitamin C supplementation in elderly hospitalised patients with acute respiratory infections. International Journal for Vitamin and Nutrition Research, 64(3), 212-219.

Im, J. H., Je, Y. S., Baek, J., Chung, M.-H., Kwon, H. Y. \& Lee, J.-S. (2020). Nutritional status of patients with COVID-19. International Journal of Infectious Diseases, 100, 390-393. https://doi.org/10.1016/j.ijid.2020.08.018

Itelman, E., Wasserstrum, Y., Segev, A., Avaky, C., Negru, L., Cohen, D., ... Lasman, N. (2020). Clinical characterization of 162 COVID-19 patients in Israel: preliminary report from a large tertiary center. The Israel Medical Association Journal: IMAJ, 22(5), 271-274.

Jaggers, G. K., Watkins, B. A. \& Rodriguez, R. L. (2020). COVID-19: repositioning nutrition research for the next pandemic. Nutrition Research (New York, NY), 81, 1-6. https:// doi: 10.1016/j.nutres.2020.07.005

Liu, M., Wallin, R., Wallmon, A. \& Saldeen, T. (2002). Mixed tocopherols have a stronger inhibitory effect on lipid peroxidation than $\alpha$-tocopherol alone. Journal of Cardiovascular Pharmacology, 39(5), 714-721.

Loprinzi, P. D., \& Hall, M. E. (2015). Physical activity and dietary behavior with red blood cell distribution width. Phys- 
iology \& Behavior, 149, 35-38. https://doi.org/10.1016/j. physbeh.2015.05.018

Muscogiuri, G., Barrea, L., Savastano, S. \& Colao, A. (2020). Nutritional recommendations for CoVID-19 quarantine. European Journal of Clinical Nutrition, 74, 850-851. https:// doi.org/10.1038/s41430-020-0635-2

Naik, S. R., Gupta, P., Khaitan, T. \& Shukla, A. K. (2020). Reduced levels of serum vitamin B12 in symptomatic cases of oral lichen planus: A cross-sectional study. Journal of Oral Biology and Craniofacial Research, 10(4), 578-582. https:// doi.org/10.1016/j.jobcr.2020.07.010

NIJZ. (2020). Referenčne vrednosti za energijski vnos ter vnos hranil. Retrived from https://www.nijz.si/sites/www.nijz.si/ files/uploaded/referencne_vrednosti_2020_3_2.pdf

Rogero, M. M., Leão, M. d. C., Santana, T. M., de MB Pimentel, M. V., Carlini, G. C., da Silveira, T. F., ... Castro, I. A. (2020). Potential benefits and risks of omega- 3 fatty acids supplementation to patients with COVID-19. Free Radical Biology and Medicine, 156, 190-199. https://doi.org/10.1016/j. freeradbiomed.2020.07.005

Shakoor, H., Feehan, J., Al Dhaheri, A. S., Ali, H. I., Platat, C., Ismail, L. C., ... Stojanovska, L. (2020). Immune-boosting role of vitamins D, C, E, zinc, selenium and omega-3 fatty acids: Could they help against COVID-19? Maturitas, 143, 1-9. https://doi.org/10.1016/j.maturitas.2020.08.003

Solomons, N. W. (2012). Vitamin A. In J. W. Erdman \& I. A. Macdonald \& S. H. Zeisel (Eds.), Present knowledge in $\mathrm{Nu}$ trition (pp. 149 - 184). Hong Kong, A John Wiley \& Sons, Ltd., Publication.

Tan, C. W., Ho, L. P., Kalimuddin, S., Cherng, B. P. Z., Teh, Y. E., Thien, S. Y., ... Nagarajan, C. (2020). A cohort study to evaluate the effect of combination Vitamin D, Magnesium and Vitamin B12 (DMB) on progression to severe outcome in older COVID-19 patients. Nutrition, 79-80, 111017. https://doi.org/10.1016/j.nut.2020.111017

Terry, E. N., \& Diamond A. M. (2012). Selenium. In J. W. Erdman \& I. A. Macdonald \& S. H. Zeisel (Eds.), Present knowl- edge in Nutrition (pp. 521 - 539). Hong Kong, A John Wiley \& Sons, Ltd., Publication.

Te Velthuis, A. J., van den Worm, S. H., Sims, A. C., Baric, R. S., Snijder, E. J. \& van Hemert, M. J. (2010). $\mathrm{Zn}^{2+}$ inhibits coronavirus and arterivirus RNA polymerase activity in vitro and zinc ionophores block the replication of these viruses in cell culture. PLOS pathogens, 6(11), e1001176. https:// doi.org/10.1371/journal.ppat.1001176

Wiltshire, E., Peña, A. S., MacKenzie, K., Shaw, G. \& Couper, J. (2020). High dose folic acid is a potential treatment for pulmonary hypertension, including when associated with COVID-19 pneumonia. Medical Hypotheses, 143, 110142. https://doi.org/10.1016/j.mehy.2020.110142

WHO. (2020a). Nutrition advice for adults during the COVID-19 outbreak. Retrived from: http://www.emro.who.int/ nutrition/nutrition-infocus/nutrition-advice-for-adultsduring-the-covid-19-outbreak.html

WHO. (2020b). Coronavirus disease (COVID-19): Food safety and nutrition. Retrived from https://www.who.int/newsroom/q-a-detail/coronavirus-disease-covid-19-food-safety-and-nutrition

Wu, D., \& Meydani, S. N. (2019). Vitamin E, Immune Function, and Protection Against Infection. Vitamin E in Human Health, In: Weber P., Birringer M., Blumberg J., Eggersdorfer M., Frank J. (Eds) Vitamin E in Human Health. Nutrition and Health. Humana Press pp. 371-384. Humana Press, Cham. https://doi.org/10.1007/978-3-030-05315-4_26

Zhang, J., Taylor, E. W., Bennett, K., Saad, R. \& Rayman, M. P. (2020). Association between regional selenium status and reported outcome of COVID-19 cases in China. The American Journal of Clinical Nutrition, 111(6), 1297-1299. https:// doi.org/10.1093/ajcn/nqaa095

Zhou, Y.-F., Luo, B.-A. \& Qin, L.-L. (2019). The association between vitamin $\mathrm{D}$ deficiency and communityacquired pneumonia: A meta-analysis of observational studies. Medicine, 98(38), e17252. https://doi: 10.1097/ MD.0000000000017252 